\title{
Neoseiulus californicus preying on Tenuipalpus heveae ${ }^{1}$
}

\author{
Eliamara Marques da Silva², Luciana Cláudia Toscano ${ }^{3}$, \\ Milene Alves-Eigenheer ${ }^{4}$, Wilson Itamar Maruyama ${ }^{3}$, Abimael Gomes da Silva $^{5}$
}

\section{ABSTRACT}

The spread of Tenuipalpus heveae Baker (Acari: Tenuipalpidae) can be controlled by managing predatory species such as Neoseiulus californicus (McGregor) (Acari: Phytoseiidae). This study aimed to evaluate the predation of $N$. californicus at different biological phases on $T$. heveae at different development stages. The experiments were carried out under laboratory-controlled conditions, counting the number of predated individuals by development stage after 24, 48 and 72 h. N. californicus, in all phases, consumed $T$. heveae, with a higher consumption of nymphs and larvae by adult predators. Both sexes of adult predators exhibited predation efficiency, but females showed a greater acceptance of adult preys than males. The daily rate of adult predation decreased over time; however, the highest consumption took place in the first $24 \mathrm{~h}$.

KEYWORDS: Phytoseiidae, biological control, predatory mite.

\section{INTRODUCTION}

Phytophagous mites are an economic problem due to their effect on crops (Vacante 2010, Navia et al. 2013, Kumari \& Srinivas 2018). The rubbertree red flat mite Tenuipalpus heveae Baker (Acari: Tenuipalpidae) is the most important phytophagous mite in southeastern Brazil (Vieira et al. 2010, Martins et al. 2012), Mato Grosso (Ferla \& Moraes 2008) and Mato Grosso do Sul (Rocha et al. 2019) states, directly affecting the rubber tree yield. Its occurrence at a density level that causes defoliation in plants is seasonal, with the highest population

\section{RESUMO}

Neoseiulus californicus predando Tenuipalpus heveae

A propagação de Tenuipalpus heveae Baker (Acari: Tenuipalpidae) pode ser controlada utilizando-se o manejo de espécies predadoras como Neoseiulus californicus (McGregor) (Acari: Phytoseiidae). Objetivou-se avaliar a predação de $N$. californicus em diferentes fases biológicas sobre $T$. heveae em diferentes estágios de desenvolvimento. Os experimentos foram conduzidos em condições laboratoriais controladas, contando-se o número de indivíduos predados por fase de desenvolvimento após 24, 48 e 72 h. N. californicus, em todas as fases, consumiu T. heveae, com maior consumo de ninfas e larvas por predadores adultos. Ambos os sexos de predadores adultos demonstraram eficiência de predação; porém, as fêmeas apresentaram maior aceitação a presas adultas do que machos. A taxa diária de predação de adultos foi reduzida ao longo do tempo; contudo, o maior consumo ocorreu nas primeiras $24 \mathrm{~h}$.

PALAVRAS-CHAVE: Phytoseiidae, controle biológico, ácaro predador.

peaks observed in the first half of the year, in Brazil, usually after periods of low rainfall and decreasing temperatures (Martins et al. 2010). These species develop preferentially along the ribs on the abaxial face of the leaves, causing symptoms such as bronzing and early drop (Pontier et al. 2001, Martins et al. 2010).

The tactic most widely used to control phytophagous mites on rubber trees is the application of synthetic acaricides (Van Leeuwen et al. 2015), which can cause environmental problems such as soil and water contamination and reduction in the amount of natural enemies (Castiglioni et al. 2002,

\footnotetext{
${ }^{1}$ Received: July 07, 2020. Accepted: Sep. 15, 2020. Published: Dec. 16, 2020. DOI: 10.1590/1983-40632020v5064329.

${ }^{2}$ Universidade Estadual Paulista, Faculdade de Ciências Agrárias e Veterinárias, Jaboticabal, SP, Brasil. E-mail/ORCID: eliamaramarques@outlook.com/0000-0002-4152-2046.

${ }^{3}$ Universidade Estadual de Mato Grosso do Sul, Unidade Universitária de Cassilândia, Cassilândia, MS, Brasil. E-mail/ORCID: toscano@uems.br/0000-0001-9634-8535, wilsonmaruyama@uems.br/0000-0003-4208-1841.

${ }^{4}$ Universidade Estadual Paulista, Instituto de Biociências, Rio Claro, SP, Brasil. E-mail/ORCID: mileneaae@gmail.com/0000-0002-6287-290X.

${ }^{5}$ Universidade Estadual Paulista, Faculdade de Engenharia, Ilha Solteira, SP, Brasil. E-mail/ORCID: ag.silva@unesp.br/0000-0001-7146-9226.
} 
Castelo-Grande et al. 2010, Montagner et al. 2014). Thus, alternative strategies are recommended, with emphasis on biological control using predatory mites.

The most common predatory mites naturally found in 61 Brazilian rubber plantations belong to the 60 Phytoseiidae and Stigmaeidae families (Feres et al. 2002, Bellini et al. 2005, Ferla \& Moraes 2008, Castro 2016). The main species used as biological agents are Phytoseiulus macropilis (Banks) and Neoseiulus californicus (McGregor), which have been successfully used in strawberry, tomato and ornamental crops, among others (Ferla et al. 2007, Bellini 2008, Sato 2009). The presence of $N$. californicus was reported in Syagrus oleracea (Mart.) Becc, when intercropped with rubber tree (Bellini et al. 2005).

The predatory mite $N$. californicus varies from straw to dark yellow color and feeds preferentially on Tetranychus urticae Koch (Tetranychidae), with a higher consumption by adult females. However, in the absence of this prey, they can consume other species of mites and thrips, what allows them to remain on plantations for prolonged periods (McMurtry et al. 2013). Except for the potential of $N$. californicus in the management of phytophagous mites, no information is available regarding its effect on $T$. heveae. As such, this study aimed to evaluate the predation of $N$. californicus at different biological phases on $T$. heveae at different development stages.

\section{MATERIAL AND METHODS}

The experiments were carried out at the Universidade Estadual de Mato Grosso do Sul, in Cassilândia, Mato Grosso do Sul state, Brazil, from May to July 2016, in a room under controlled conditions (temperature $=25 \pm 2{ }^{\circ} \mathrm{C}$; relative humidity $=70 \pm 10 \%$; photophase $=14 \mathrm{~h}$ ).

The experimental design was randomized, in a $4 \times 4$ factorial arrangement, totaling 16 treatments, with 12 replications, comprising the groups predatory (larva, nymph, adult male and adult female) and phytophagous (eggs, larvae, nymphs and adults) mites.

The predatory mites were obtained from a colony provided by the Instituto Biológico do Estado de São Paulo (Campinas, São Paulo state, Brazil). The breeding stock was placed in Petri dishes (14-cm diameter), each containing a piece of polyethylene foam moistened with distilled water and a common jack bean leaf (Canavalia ensiformes) wrapped in hydrophilic cotton wool (Sato 2009). Cotton threads covered with a coverslip $(20 \times 20 \mathrm{~mm})$, some empty and some with castor bean pollen (Ricinus communis L.), were placed on the bean leaf to shelter and feed the predatory mites. The individuals were not fed for $24 \mathrm{~h}$ before each experiment, preventing interference from previously supplied food. Pregnant adults were isolated in individual dishes for oviposition and subsequent larval eclosion and, only then, the larvae were collected. The other stages were transferred immediately after the stage change (Cardoso et al. 2010).

To gather the $T$. heveae, leaves of the rubber clone RRIM 600 were collected at the experimental field of the Universidade Estadual de Mato Grosso do Sul. In the laboratory, 5-cm leaf disks were obtained using a puncher and stylus, separating the mites into groups of 20 individuals, according to their development stage (egg, larva, nymph or adult). The disks were deposited in Petri dishes (9-cm diameter) containing a cotton layer moistened with distilled water.

In order to confirm both the predator and phytophagous mite development stages, nymphs and adults collected directly from the breeding dishes were analyzed in a stereomicroscope and mounted on slides. The larval stage was easily identifiable, since they have three pairs of legs, as opposed to nymphs and adults (4 pairs), and testing started after eclosion.

The evaluations were performed according to the development phase of the predatory mite, that is, after $24 \mathrm{~h}$ for larvae and nymphs, and after 24, 48 and $72 \mathrm{~h}$ for adult females and males. After this evaluation period, the natural mortality of the preys was verified. The numbers of predated and non-predated $T$. heveae were counted. The values of predated mites were compared at $1 \%$ of significance by applying the Scott-Knott test. The period effect (h) was evaluated by regression analysis, adopting, as a criterion for model selection, the magnitude of the regression coefficients $\left(\mathrm{R}^{2}\right)$ at $5 \%$ of significance. The data were submitted to analysis of variance using the Sisvar statistical software.

\section{RESULTS AND DISCUSSION}

The results confirm that the $N$. californicus mite consumes $T$. heveae. In all stages, the predator consumed T. heveae in a 24-h period (Table 1), except for the predator larvae $\mathrm{x}$ adult phytophagous mite 
Table 1. Mean ( \pm standard error) predation of Tenuipalpus heveae at different development stages predated by Neoseiulus californicus at different stages during a $24-\mathrm{h}$ period.

\begin{tabular}{|c|c|c|c|c|}
\hline \multirow{2}{*}{ Tenuipalpus heveae } & \multicolumn{4}{|c|}{ - Neoseiulus californicus development stages - } \\
\hline & Larvae & Nymphs & Females & Males \\
\hline$\overline{\text { Egg }}$ & $0.08 \pm 0.08 \mathrm{bB}^{(1)}$ & $1.08 \pm 0.22 \mathrm{cA}$ & $1.58 \pm 0.23 \mathrm{cA}$ & $1.75 \pm 0.22 \mathrm{dA}$ \\
\hline Larva & $1.41 \pm 0.26 \mathrm{aB}$ & $10.25 \pm 0.45 \mathrm{aA}$ & $9.91 \pm 0.61 \mathrm{aA}$ & $10.25 \pm 0.35 \mathrm{aA}$ \\
\hline Nymph & $0.83 \pm 0.02 \mathrm{aB}$ & $8.00 \pm 0.30 \mathrm{bA}$ & $9.50 \pm 0.65 \mathrm{aA}$ & $8.58 \pm 0.70 \mathrm{bA}$ \\
\hline Adult & $0.00 \pm 0.00 \mathrm{bC}$ & $1.25 \pm 0.21 \mathrm{cB}$ & $4.83 \pm 0.47 \mathrm{bA}$ & $3.83 \pm 0.32 \mathrm{cA}$ \\
\hline F (predator $\mathrm{x}$ prey) & & $22.15 * *$ & & \\
\hline CV $(\%)$ & & $12.12 * *$ & & \\
\hline
\end{tabular}

interaction, probably due to the difference in size and difficulty in handling (Franco et al. 2007), although the predator larvae are considered facultative feeders (Schausberger \& Croft 1999). The predator nymphs also exhibited a greater preference for larva and nymph preys (Argolo et al. 2020). Eggs and adults were poorly accepted by the predator nymphs, corroborating Cardoso et al. (2010), for Euseius citrofolius Denmark \& Muma (Acari: Phytoseiidae). The phytophagous mite egg was the least predated development phase, consumed most by male adults and least by larvae. These results may be related to the difficulty in breaking the egg chorion (Franco et al. 2007).

Adult predators of both sexes were efficient in consuming $T$. heveae in a $24-\mathrm{h}$ period (Table 1). Male predators displayed a mean predation capacity of 10.25 for larvae, 8.58 for nymphs and 3.83 for adult preys, while the females exhibited 9.91 for larvae, 9.5 for nymph and 4.83 for adult preys, showing a greater acceptance than that found by Cardoso et al. (2010), when evaluating $T$. heveae and E. citrofolius. Adult females of Phytoseiidae show a high potential predation, due to their agile locomotion and larger size, in addition to greater nutritional requirements and energy expenditure during the oviposition period (Shipp \& Whitfield 1991, Franco et al. 2007).
In general, the mobile immature stages of the phytophagous mite faced the highest predation by all the predator stages. The same preference for immature stages was observed by Marafeli (2011), for $N$. californicus feeding on $T$. urticae, but with even higher intake rates, likely because it has a preference for $T$. urticae (McMurtry et al. 2013). Concerning the sex of adult predators during the study period, males and females demonstrated acceptance to the $T$. heveae stages, except for the adult stage of preys, which was better accepted by females (Table 2), similarly to what was reported by Franco et al. (2007) and Cañarte et al. (2017).

The daily adult predator consumption of T. heveae decreased after each 24-hour period (Figure 1). The highest intake rate was in the first $24 \mathrm{~h}$, with a higher predation of nymphs, larvae and eggs and a lower acceptance of adult preys. In the 48-h period, the rates were lower, but in the same order of preference for immature stages of the rubber tree red flat mite. After $72 \mathrm{~h}$, the adult prey stage was still the least preferred by the predator. This decrease in the larval consumption over time can be attributed to the lower amount of food supplied. The rate of consumed adult $T$. heveae was similar in the 48-h and 72-h assessments, differently from the other stages, where the consumption decreased

Table 2. Mean ( \pm standard error) predation ratio of Tenuipalpus heveae at different development stages by Neoseiulus californicus males and females over a 72-h period.

\begin{tabular}{|c|c|c|c|c|}
\hline \multirow{2}{*}{ Neoseiulus californicus } & \multicolumn{4}{|c|}{-Tenuipalpus heveae } \\
\hline & Eggs & Larvae & Nymphs & Adults \\
\hline Males & $1.19 \pm 0.31 \mathrm{aD}^{(1)}$ & $5.75 \pm 0.34 \mathrm{aA}$ & $4.50 \pm 0.23 \mathrm{aB}$ & $2.63 \pm 0.34 \mathrm{bC}$ \\
\hline Females & $1.11 \pm 0.26 \mathrm{aC}$ & $5.58 \pm 0.23 \mathrm{aA}$ & $5.11 \pm 0.29 \mathrm{aA}$ & $5.58 \pm 0.24 \mathrm{aA}$ \\
\hline F (predator sex x prey phase) & $3.7 * *$ & & & \\
\hline $\mathrm{CV}(\%)$ & 14.0 & & & \\
\hline
\end{tabular}



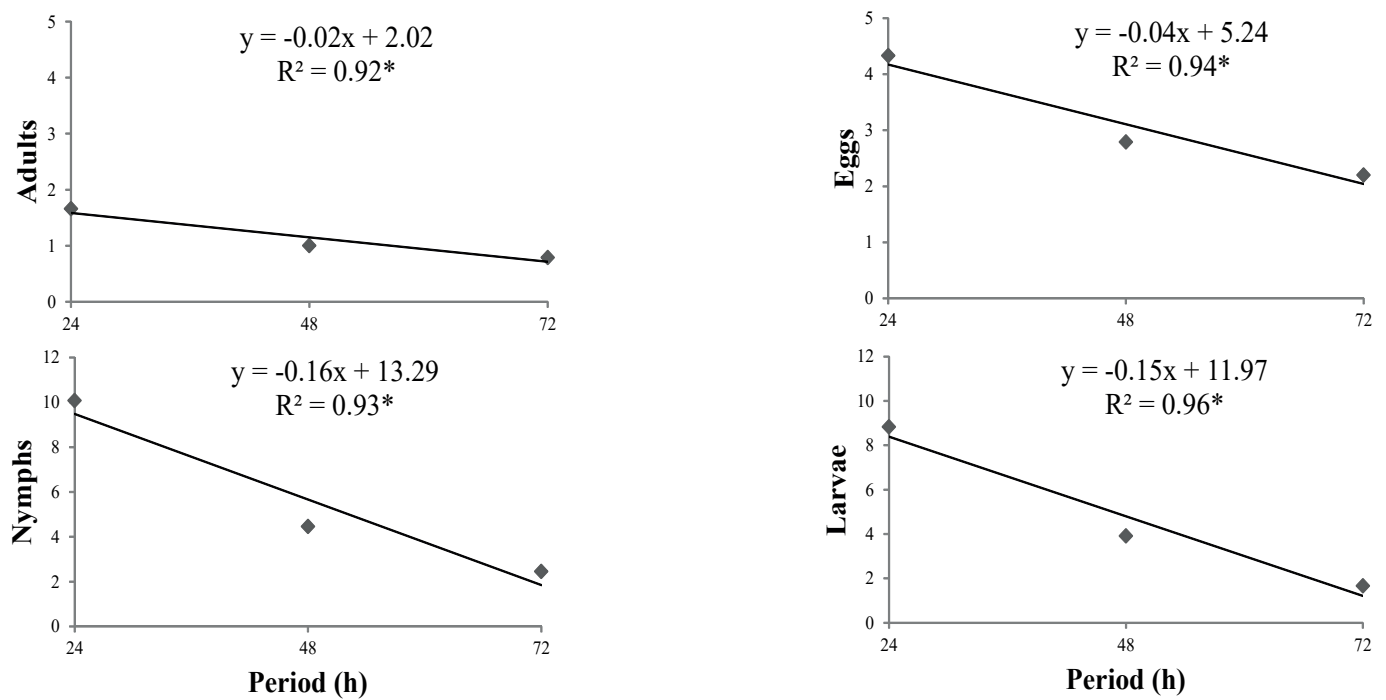

Figure 1. Predation of Tenuipalpus heveae at different development stages by adult Neoseiulus californicus over 24,48 and $72 \mathrm{~h}$.

according to the evaluated period. This decrease in the number of predated mites over time was also observed by Cardoso et al. (2010), whose results for the consumption behavior of E. citrofolius on T. heveae were similar to the findings of this study, and possibly associated with predator satiation.

The present study is a preliminary step to understand T. heveae as food for $N$. californicus. Thus, the predator biology and its release in the field have not been evaluated yet. It is believed that, if there is a high predator mortality associated with a reduced consumption in the period, it could be suggested that the prey would not be suitable for the predator. This predatory mite has been reported in crops intercropped with rubber tree (Bellini et al. 2005), being present in the same agrosystem. Thus, further studies must be carried out.

The results obtained in this study indicate the predation potential of $N$. californicus biological phases on $T$. heveae development stages. Understanding the relationship between predatory and phytophagous mites is essential for assessing the behavior of these organisms.

\section{CONCLUSIONS}

1. The biological phases of phytophagous mites interfere with the feeding behavior of predatory mites;

2. The food preference stages of the pest are variable among adult female and male predator mites;
3. The daily adult predator intake of Tenuipalpus heveae decreases after each $24-\mathrm{h}$ period. Possibly, this food source is not suitable for the predator.

\section{ACKNOWLEDGMENTS}

The authors would like to thank the Fundação de Apoio ao Desenvolvimento do Ensino, Ciência e Tecnologia do Estado de Mato Grosso do Sul, Conselho Nacional de Desenvolvimento Científico e Tecnológico e Coordenação de Aperfeiçoamento de Pessoal de Nível Superior (Fundect/CNPq/UEMS n ${ }^{\circ}$ 08/2015; PROAP/ Capes $\left.n^{\circ} 817199 / 2015\right)$, for the funding provided.

\section{REFERENCES}

ARGOLO, P. S.; REVYNTHI, A. M.; CANON, M. A.; BERTO, M. M.; ANDRADE, D. J.; DÖKER, I.; RODA, A.; CARRILHO, D. Potential of predatory mites for biological control of Brevipalpus yothersi (Acari: Tenuipalpidae). Biological Control, v. 149, e104330, 2020.

BELLINI, M. R. Manejo de Tetranycus urticae Koch (Acari: Tetranychidae) em plantas ornamentais. 2008. Tese (Doutorado em Ecologia Aplicada) - Centro de Energia Nuclear na Agricultura, Escola Superior de Agricultura Luiz de Queiroz, Piracicaba, 2008.

BELLINI, M. R.; MORAES, G. J.; FERES, R. J. F. Ácaros (Acari) de dois sistemas de cultivo da seringueira no noroeste do estado de São Paulo. Neotropical Entomology, v. 34, n. 3, p. 475-484, 2005. 
CAÑARTE, E.; SARMENTO, R. A.; VENZON, M.; PEDRO-NETO, M.; FERREIRA JUNIOR, D. F.; SANTOS, F. A.; PALLINI, A. Suitability and nutritional requirements of the predatory mite Typhlodromus transvaalensis, a potential biological control agent of physic nut pest mites. Biological Control, v. 115, n. 1, p. 165-172, 2017.

CARDOSO, M. S. M.; VIEIRA, M. R.; FIGUEIRA, J. C. V.; SILVA, H. A. S. Atividade predatoria de Euseius citrifolius Denmark \& Muma (Acari: Phytoseiidae) sobre Tenuipalpus heveae Baker (Acari: Tenuipalpidae). Arquivos do Instituto Biológico, v. 77, n. 3, p. 471-476, 2010.

CASTELO-GRANDE, T.; AUGUSTO, P. A.; MONTEIRO, P.; ESTEVEZ, A. M.;BARBOSA, D. Remediation of soils contaminated with pesticides: a review. International Journal of Environmental Analytical Chemistry, v. 90, n. 3-6, p. 438-467, 2010.

CASTIGLIONI, E.; VENDRAMIM, J. D.; TAMAI, M. A. Evaluación del efecto tóxico de extractos acuosos y derivados de meliáceas sobre Tetranychus urticae (Koch) (Acari: Tetranychidae). Agrociencia, v. 6, n. 2, p. 75-82, 2002.

CASTRO, E. B. Estudos taxonômicos e filogenéticos de Tenuipalpus Donnadieu (sensu stricto e sensu lato) e Colopalpus Pritchard \& Baker (Acari, Tenuipalpidae). 2016. Tese (Doutorado em Biologia Animal) - Universidade Estadual Paulista Júlio de Mesquita Filho, São José do Rio Preto, 2016.

FERES, R. J. F.; ROSSA-FERES, D. C.; DAUD, R. D.; SANTOS, R. S. Diversidade de ácaros (Acari, Arachnida) em seringueiras (Hevea brasiliensis Muell. Arg.) na região noroeste do estado de São Paulo, Brasil. Revista Brasileira de Zoologia, v. 19, n. 1, p. 137-144, 2002.

FERLA, N. J.; MARCHETTI, M. M.; GONÇALVES, D. Ácaros predadores (Acari) associados à cultura do morango (Fragaria sp., Rosaceae) e plantas próximas no estado do Rio Grande do Sul. Biota Neotropica, v. 7, n. 2, p. 103-110, 2007.

FERLA, N. J.; MORAES, G. J. Flutuação populacional e sintomas de dano por ácaros (Acari) em seringueira no estado do Mato Grosso, Brasil. Revista Árvore, v. 32, n. 2 , p. 365-376, 2008.

FRANCO, R. A.; REIS, P. R.; ZACARIAS, M. S.; ALTOÉ, B. F. Potencial de predação de três espécies de fitoseídeos sobre Oligonychus ilicis (McGregor, 1917) (Acari: Tetranychidae). Coffee Science, v. 2, n. 2, p. 175-182, 2007.

KUMARI, M. H. S.; SRINIVAS, M. P. Pests attacking medicinal and aromatic plants in India: a review. Journal of Entomology and Zoology Studies, v. 6, n. 5, p. 201205, 2018.
MARAFELI, P. P. Histórico de vida de Neoseilus californicus (McGregor, 1954) tendo como alimento Tetranychus urticae Koch, 1836 (Acari: Phytoseiidae, Tetranychidae) e pólen de mamoneira (Ricinus communis L.). 2011. Dissertação (Mestrado em Entomologia) Universidade Federal de Lavras, Lavras, 2011.

MARTINS, G. L. M.; VIEIRA, M. R.; BARBOSA, J. C.; DINI, T. A.; MANZANO, A. M.; ALVES, B. S.; SILVA, R. M. Distribuição espacial de Tenuipalpus heveae Baker (Acari: Tenuipalpidae) na cultura da seringueira. Neotropical Entomology, v. 39, n. 5, p. 703-708, 2010.

MARTINS, G. L. M.; VIEIRA, M. R.; BARBOSA, J. C.; DINI, T. A.; MANZANO, A. M.; ALVES, B. M. S.; SILVA, R. M. Distribuição espacial de Calacarus heveae Feres na cultura da seringueira em Marinópolis - São Paulo. Revista Árvore, v. 36, n. 2, p. 211-217, 2012.

MCMURTRY, J. A.; MORAES, G. J.; FAMAH SOURASSOU, N. Revision of the lifestyles of phytoseiid mites (Acari: Phytoseiidae) and implications for biological control strategies. Systematic and Applied Acarology, v. 18, n. 4, p. 297-320, 2013.

MONTAGNER, C. C.; VIDAL, C.; ACAYABA, R. D.; JARDIM, W. F.; JARDIM, I. C. S. F.; UMBUZEIRO, G. A. Trace analysis of pesticides and an assessment of their occurrence in surface and drinking waters from the state of São Paulo (Brazil). Analytical Methods, v. 6, n. 17, p. 6668-6677, 2014.

NAVIA, D.; GONDIM, M. G. C.; ARATCHIGE, N. S.; MORAES, G. J. de. A review of the status of the coconut mite, Aceria guerreronis (Acari: Eriophyidae), a major tropical mite pest. Experimental and Applied Acarology, v. 59, n. 1-2, p. 67-94, 2013.

PONTIER, K. J. B.; MORAES, G. J.; KREITER, S. Biology of Tenuipalpus heveae (Acari, Tenuipalpidae) on rubber tree leaves. Acarologia, v. 41, n. 4, p. 423-427, 2001.

ROCHA, L. F.; TOSCANO, L. C.; MARTINS, G. L. M.; SILVA, E. M. Ocorrência de ácaros em seringueira irrigada em cultivo inicial. Journal of Neotropical Agriculture, v. 6, n. 2, p. 72-78, 2019.

SATO, M. M. Eficiência do ácaro predador Phytoseiulus macropilis (Banks) (Acari: Phytoseiidae) no controle de Tetranychus urticae Koch (Acari: Tetranychidae) em tomateiro. 2009. Dissertação (Mestrado em Ciências) - Escola Superior de Agricultura Luiz de Queiroz, Universidade de São Paulo, Piracicaba, 2009.

SCHAUSBERGER, P.; CROFT, B. A. Activity, feeding, and development among larvae of specialist and generalist phytoseiid mite species (Acari: Phytoseiidae). 
Environmental Entomology, v. 28, n. 2, p. 322-329, 1999.

SHIPP, J. L.; WHITFIELD, G. H. Functional response of the predatory mite Amblyseius cucumeris (Acari: Phytoseidae) on wester flower thrips Frankliniella occidentalis (Thysanoptera: Thripidae). Environmental Entomology, v. 20, n. 2, p. 694-699, 1991.

VACANTE, V. Review of the phytophagous mites collected on citrus in the world. Acarologia, v. 50, n. 2, p. 221-241, 2010.
VAN LEEUWEN, T.; TIRRY, L.; YAMAMOTO, A.; NAUEN, R.; DERMAUW, W. The economic importance of acaricides in the control of phytophagous mites and an update on recent acaricide mode of action research. Pesticide Biochemistry and Physiology, v. 121, n. 1, p. 12-21, 2015.

VIEIRA, M. R.; GOMES, E. C.; SILVA, H. A. S. Redução na produção de látex da seringueira provocada pela infestação de ácaros. Revista Ceres, v. 57, n. 5, p. 608613, 2010. 